\title{
Analysis on the Application and Inheritance of Ula Culture in Modern Residence
}

\author{
Ruifeng Tao \\ Art College \\ Northeast Electric Power University \\ Jilin, China
}

\author{
Fengming Guo \\ Art College \\ Northeast Electric Power University \\ Jilin, China
}

\begin{abstract}
Ula is one of the clan tribes of Jurchen. It is also a nickname of Manchu because they dwelt along Songhua River in Jilin, Jinlin province for generations. Ula Street Town of Jilin City has a long history and culture. It is not only rich in folk customs, but also famous for Ula culture at home and abroad. The design of modern residence should reflect locality and nationality, which is also a powerful means to highlight the characteristics of modern residence design. The embedding of this special technique will also make the space design more appealing. Nowadays, although the Ula national customs show distinct regional characteristics, there are few embodiments of Ula-style designs in residential design. We should refine and sublimate the traditional living culture elements of Ula and make full use of the traditional national cultural elements to make our interior design more national and vital, and achieve a good decorative style effect. The paper will study the concept of Ula traditional residential design and research how to better apply the long-standing Ula culture in modern dwellings and inherit it.
\end{abstract}

Keywords-Ula culture; modern residence; application; inheritance

\section{INTRODUCTION}

Ula Street Town is a famous Manchu Town in the northeast China, located in the upper reaches of the Songhua River, which belongs to Longtan District of Jilin City. Ula Street Town is the birthplace of ethnic minority Manchu. In the long river of history, it has always been an important activity center of ethnic minority Manchus and also witnessed the birth, growth, expansion, rise and development of a nation.

The ancient architectural heritage of Ula Street Town is quite rich, and there are many existing cultural relics, with rich regional folk culture and Shaman religious culture. Ula Street is one of the birthplaces of Ula. Its culture is mainly Ula culture that inherits and absorbs many Jurchen civilizations, Mongolian civilizations and Han civilizations. There are 5 provincial-level cultural relics protection units and 1 municipal-level cultural relics protection unit in Ula street Town area; 1 national intangible cultural heritage and 11 provincial-level intangible cultural heritage; various museums have collected many cultural relics. The main traditional ancient buildings are the original "Four Halls", "Eight Temples", "Four Houses", "Two Offices and Two Cities", and "Three Mansions".
Folk culture is the sublimation of life as well as the sublimation of ordinary people's ordinary life into the cultural field. The folk culture of Ula Street Town has not only the original residential houses of the Ula mud wall, but also traditional foods such as water dumplings, small meat rice, Long $\mathrm{Hu}$ Dou, pastry, caramel treats, and the Eight Bowls. These folk cultures all can bring people different regional culture feelings. People who come to play can not only taste the delicious food, but also watch the dance performances of Ula's big Yangko, shaman dance performance, single drum waist bell, and Qinglong dance. The folk culture of Ula gradually evolved into an indispensable part of the Ula folk culture in the historical river, which deeply influenced the people of Ula. Ula Street Town of Jilin City was the earliest activity area of the Sushen ancestors, and the emperor of the Qing Dynasty also left a footprint here. The various intangible cultural heritages in the town of Ula Street include Shamanism of Ula and the music of shaman, as well as the dance, diet, and falcon custom of Ula. Under the rapid development of the new era, the impact of various external factors on Ula culture has caused some of this folklore to cease to exist in daily life, and some are forgotten in the dark corner. However, people's awareness of protection has gradually increased in recent years. There are also some excellent intangible cultures that have been passed down and their good places are promoted.

\section{A. The Origin of Ula Culture}

Wula Street Town is located in Jilin City in northeastern China. As early as 5,000 years ago in the Neolithic Age, the ancestors of the Ula people, Sushen survived here, and the $\mathrm{Xi}$ Tuanshan culture left many precious ancient sites here three thousand years ago. From the Han Dynasty to the Yuan Dynasty, Bohai State established the city walls here, which was the beginning of the city construction of Ula Street, and was destroyed by the war later.

After the founding of New China, it was under the jurisdiction of Yongji County of Jilin Province in 1999, and has been under the jurisdiction of Longtan District of Jilin City since December 1999. Nowadays, Ula Street Town is listed as a national key town. It has distinct national and regional characteristics and is a true continuation of the historical development of Ula. There is also the saying that "Ula came ahead of Jilin". 
The original Manchus lived within the black mountains and white water in the northeastern forests, living a nomadic fishing and hunting life. Although their names have been changed for many times in the history in Han Classics, Wuji, Mohe, or the Jurchen and Manchu who once governed the country lived on this same piece of land. This place with white mountain and black soil in northeast China has always been the home of the ancestors of Ula.

In the long history of China's civilization, from the ancestors of Ula Sushen to the Manchuria in modern times, Ula Street Town witnessed the history of Manchu development from beginning to end. From the primitive tribes, Ula gradually passed through the historical elimination and self-progress, and became an excellent nation. It has added vitality to the China and enriched the Chinese civilization. Especially in the process of China's transition from the old society to the new society, it integrates itself with the Chinese nation into a community in a natural way like flowing water. The unique charm of Ula culture is the course of its development and the cultural context, which is fully reflected in its glorious past and present.

\section{B. The Influence of Ula Religious Culture on the Living Environment}

The religion of the Ula is different from the Buddhist and Taoism believed in the Central Plains. Although there was also Buddhism and Lamaism, the most widely known and representative religion of the Ula people is Shamanism passed down by the wizard.

The inheritance of shamanism is long-standing, which belongs to polytheism. The believers believe in many gods. From nature to ancestor spirits, the figure of shaman gods can be found. Shamanism had an impact on the Jurchen very early, and it still affected all aspects of the Qing government.

Ula religious culture has a great impact on people's residential buildings, including royal architecture. The Sanheyuan and Siheyuan, traditional residence of the ordinary Ula people and the Ningshou Palace and Kunning Palace in the royal buildings are all influenced by the Ula culture. In these buildings, the layout of the Sanheyuan and Siheyuan is symmetrical. In addition, even the gates of the houses will be placed on the central axis of the building. This layout is obviously a feature of the Ula dwellings.

In the traditional residence of Ula, there is room especially for fete. Most of the Ula people will set up the "Suoluo Rod" in the southeast of their own courtyard, which is also reflected in the southwest of the Qingning Palace in Shenyang Imperial Palace. The Ula religious culture can be seen everywhere in the life of Ula residents, affecting not only all aspects of the life of Ula people, but also the royal family's aristocratic life.

\section{The Impact of the Natural Environment on Traditional Residences in Ula}

Although the traditional residence of Ula is located in the northeast where the winter climate is cold, there is also a summer that is hard to bear. Besides, the ancestors of Ula have chosen to live in the mountains for the sake of national security. The climate in the mountains is cold in winter and hot in summer, so the residence of the ancestors of Ula formed the living pattern of "living in house in summer residence, while living in cave in winter", "cuoluozi" and "cellar" are the earliest residence manner of Ula. Cuoluozi, where they live in summer, is a conical "house". The top can resist rain and sinister sun. According to the custom of Ula, the different orientations in it represent different levels, and the north is the place for gods, which is the most distinguished place. Because of the cold winter, in order to resist the cold north wind, there is the form of residence: cellar. The cellar is the pit excavated three or four meters underground, in which the heated kang is placed and the warmth is good.

Due to the adverse weather in the northeast and the living habits, Ula ancestors built their houses at higher elevations to prevent floods and beasts. When the ancestors of Ula built a fixed house, they also considered how to avoid being affected by the natural environment. For example, the heated kang is set on the north, west and south sides of the house, commonly known as the swastika kang, to protect against the cold; the residential doors are all open to the outside, in order to prevent the beasts from intruding; and the window paper with one of the eight monsters in the Northeast on it is pasted on the window to resist the snow.

\section{TRAditional RESIDENTIAL SPACE FORM OF ULA PEOPLE}

The traditional residential space form of Ula has a high status in the Ula ethnic living culture, and even has a major impact on the residential space form of the entire China. The residential space of the people can still see the mark of the traditional residential space of Ula.

\section{A. Courtyard Layout of the Traditional Residence of Ula}

In the layout of the courtyard, the most typical courtyard layout of Ula is Sanheyuan and Siheyuan. These are developed from the "Cuoluozi" and the "cellar", which is the result of the gathering of the Ula dwellings. Since Ula power entered Beijing, its culture was also influenced by the Han culture. Therefore, the central axis symmetry of the Han culture was fully reflected in the residential buildings of Ula, and the courtyard of Ula also adopted a symmetrical layout.

The biggest difference between Siheyuan of Ula and the courtyard house in Beijing lies in the location of the residential door. The old Beijing courtyard often has a residential gate in the southeast, while the gate of Ula dwelling is in the middle strictly in accordance with the central axis. People can see the center of the house from the entrance. The Siheyuan is composed of a south-facing main house and two wing rooms on the east and west sides, with a concierge set in the center, so this layout of the house is called Siheyuan. The Sanheyuan is a combination of three houses and one door.

In the traditional residences of Ula, whether it is a Sanheyuan or a Siheyuan, and whether the family is poor or 
rich, the screen wall will be built in the house. The role of the screen wall is to enhance the privacy of the house, even if the door is open, passers-by will not be able to see the situation inside the house. The screen wall is set both in the outer side and the inner side of the gate. The outer screen wall plays a large decorative role while the inner shadow wall creates a tranquil residential environment.

\section{B. The Indoor Layout of the Traditional Residence of Ula}

The indoor layouts of traditional residences of Ula include "pocket type" and "moneybag typr", which are gradually developed from the "Nagri" where the Ulan ancestors lived in the Jin Dynasty. Among them, "pocket type" is also called "bucket type", which is named for its shape. The layout of the kang in the bedroom of "pocket type" residence is two large kangs in the north and south, with a narrow kang connecting in the middle. This style of kang is called "swastika kang", and is also called "circle kang" iconically. The south side of kang is for elders while the juniors lived in the north side. The entrance door mostly opens in the first house on the east side, and some entrance doors are opened in the middle, which is called the "opposite house".

Another feature of the "moneybag type" residence is that the entrance door is in the middle of the house, and the kitchen can be seen after entering the house. The two sides are divided into the east house and the west house, and the juniors in the family should live in the east house. There are windows on both sides of the entrance door, called "horse window", and each house has a window on the south side, with kraft paper pasted outside the window to prevent snow. Each residence will have a ventilated passageway on the side gable to connect to the outside chimney for smoke evacuation.

\section{Traditional Interior Decoration Elements of Ula}

The location of Wula is near the forests of Changbai Mountain, which provides the Ula people with the necessities of building a house - wood. The winter in the northeast is extremely cold, so the activities of Ula people in the winter are naturally carried out around the fire. The people's diet and daily life are carried out on the heated kang, thus forming a unique "culture on the kang" of Ula. The kang is one of the necessary furniture for the residents of Ula, and it is also called the kangqin in some areas. Because there are usually golden decorative patterns on the cabinet, it is also known as the gold cabinet. The top of the cabinet is for the storage of quilt, the upper part can store clothes, and the bottom cabinet is the place for idle objects. The Manchu furniture in the northeast is simple in line, and the common decorative patterns include long round line, hollow-square pattern and other patterns that symbolize the happiness and auspiciousness. There are not too many complicated decorative patterns, which make the shape of this furniture straighter, simpler and more generous, representing the Manchu people's capable life style.

The Ula people admire their ancestors, so they have the custom of worshiping the ancestors, and there is ancestral board specially for worshiping ancestors in the houses of Ula people. The ancestral board is set on the wall on the west side of the upper house.

On the board, there is a wooden box called ancestral box, where there are often more than a feet white silk and the genealogy, or bows and arrows used by ancestors. As shown in "Fig. 1", the ancestral board is placed on the west wall of the upper house in this design, enshrining the bows used by the Ula ancestors.

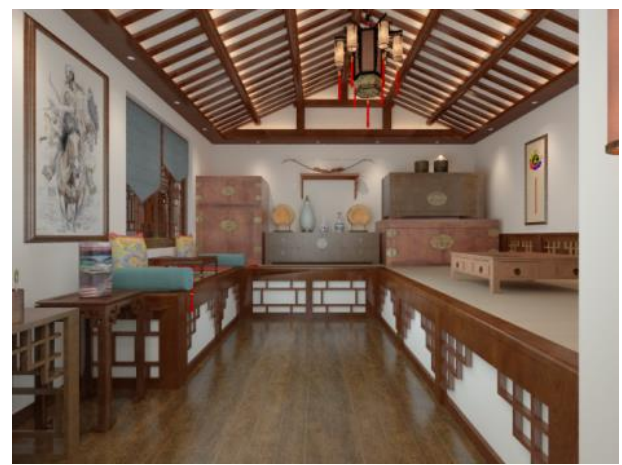

Fig. 1. Ula folk-custom reception area.

Paper-cutting is a very important element in Ula culture. Ula paper-cut contains characters, animals, auspicious words, flowers, and patterns and so on. On every festival, paper-cuts made of colored paper will be pasted on doors, windows, walls and beams to celebrate the festival.

\section{The Influence OF Ula CUlture ON MODERN RESIDENCES}

The Manchus living in the Ula Street Town of Jilin Province are ethnic minorities in China, as well as the rare ethnic minorities that established nationwide political power in the history of China. Since the ancient times, the Ula people have been active in the Ula Street Township of Jilin Province in China. Due to the influence of natural conditions, the Ula culture has also affected the residential buildings today, which makes the local residences have distinct regional characteristics.

\section{A. Influence of Shaman Culture on the Interior Space of Residence}

Religion provides people with belief, and the establishment of belief can determine the trajectory of people's life. Therefore, religious culture has always been one of the factors that have a greater influence on people's production and life, and the residence of the people is also affected by the religious culture. The Shamanism culture of Ula has a great influence on the life and architecture of Ula people. Each household of Ula has a special area for sacrificial ceremony at home, such as the ancestral box on the west wall of the room. The shaman can communicate with God in the consciousness of the Ula people, so the Ula people can carry out meal activities on the west kang only when they worship the heavens. Until today, the Ula people still believe in shamanism, and the family's spatial layout can still see traditional customs. It can be seen that the shamanic culture has far-reaching influence on modern residences. 


\section{B. The Influence of Ula Art Form on Interior Space of Residence}

In the new era, under the impact of foreign culture, Ula's living culture has also had a certain impact, and some changes have taken place. The traditional heated kang of Ula has an impact on the modern form of living. In the hotel with the theme of Qing culture, the Ula characteristic household kang cabinets and tables can be seen everywhere, reflecting the characteristic culture of Ula. However, through careful observation, it can be seen that these furniture has the characteristics of the times when meeting the characteristics of the Ula. For example, the use of modern material art paint not only avoids the excessive use of wood, but also reflects the texture, color and charm of the wood, and makes it more perfect.

\section{Influence of Ula Customs on Interior Space of Residence}

The heated kang has a long history in the Ula dwellings. The eating habits of the Ula people on the heated kang have long been an integral part of their lives, so there are still ancient forms of kang in modern rural dwellings. Even in modern buildings, modern electric kang have been used to replace heated kang.

\section{APPLICATION AND INHERITANCE OF ULA CULTURE IN MODERN RESIDENCES}

Due to the great differences in climate in different regions, the living habits are also different. Different national customs lead different regions to have different design styles. Although there are mainstream design styles in the field of modern residential design, with the continuous improvement of people's living standards, the demand for spiritual and cultural life has gradually increased and "retro style" and "national style" have already appeared in the design of contemporary houses. The Ula culture has been applied and passed down.

\section{A. Performance of Ula Traditional Living Culture in Modern Residences}

In the fast-developing contemporary era, significant progress has been made in transportation, materials, and technology, so local materials and traditional crafts and other factors are no longer restricted by transportation and transmission, and can no longer play a decisive role in modern housing. The impact on dwellings has also been weakened.

1) Performance of traditional residential space forms in modern dwellings: In traditional residences, the door is the key that connects indoor and outdoor space. In order to prevent the pedestrians outside the door from affecting the privacy of the dwelling, screen walls are set as a buffer zone. Now, people commonly live in buildings without their own courtyard, but people set up hallway, shoe cabinets, etc. at the entrance, which also played a role of the screen wall.

2) Performance of Ula's indoor color elements in modern homes: Color is a kind of visual experience. It can show the "character" and like of a nation, which is a manifestation of national culture. The colors often used in Ula traditional culture are green, yellow, blue, red, gray, etc. Ula culture uses these colors as symbols and ways of expressing emotions and thoughts. Nowadays, what use Ula color most widely is clothes. In indoor culture, Ula color is mainly reflected in various kinds of fabrics such as papercutting and furniture. Although it is not as strong and vivid as in traditional houses, it applies the essence of traditional Ula colors to indoor culture. As shown in "Fig. 2", the red and yellow colors of Manchu are used in the color selection of the decorations and the color of the lights. It also uses the wood that is used in Ula dwellings most often to highlight the atmosphere of the ancient Ula dwellings.

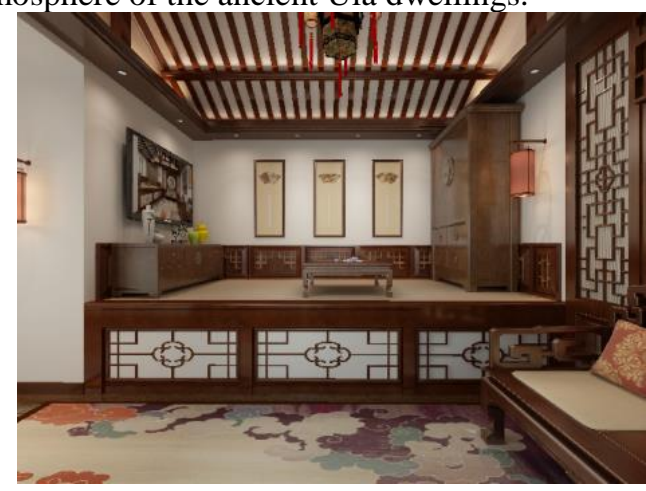

Fig. 2. Ula Folk Room.

\section{B. Performance of Shaman Culture in Modern Residences}

Shamanism has always been mysterious. In recent years, as shaman studies have gradually culminated, shaman culture has gradually been understood by more people who like the mysterious decorative items with shaman elements. In today's interior design, shaman masks, shaman totem poles, objects with shaman elements are placed as decorations in the house to add national color, or as collections for people to enjoy. There are many cases applying the symbol of shaman religion to the decoration of the house after refinement. As shown in "Fig. 3", the pattern and shape of the ornament on the incense table is taken from the shaman totem pole, and the pattern on the pillow is taken from the Manchu Eight Flag pattern.

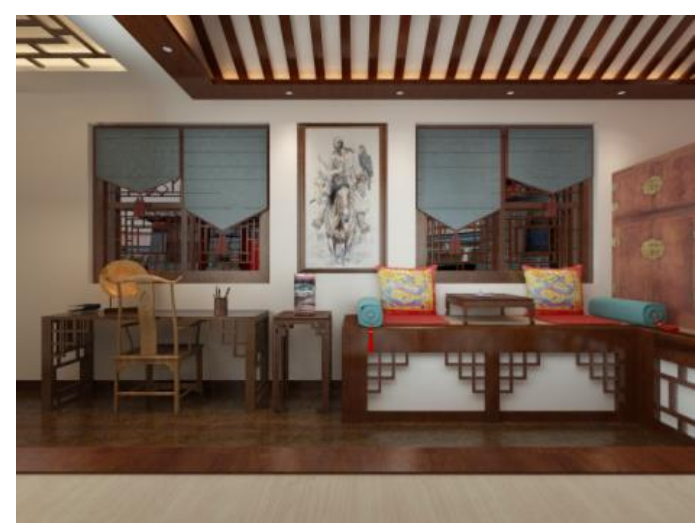

Fig. 3. Ula folk custom reception area. 


\section{The Inheritance of Ula Traditional Living Culture in Modern Dwellings}

In the contemporary inheritance of Ula traditional culture, one kind is museum and exhibition hall. This kind of environment can replicate all aspects of traditional living conditions and can create a real Ula traditional house. In this kind of environment, tourists seem to break the secret of time machine. The other is the inheritance of ordinary dwellings. It is difficult for ordinary dwellings to express the characteristics of Ula in the external facade of the building. The interior decoration style is not systematic, and most of them use traditional Ula symbols on furnishings, collectibles, wall paper cuttings, wall patterns and wooden furniture to create an indoor space with Ula characteristics.

There are still many problems in the inheritance of Ula traditional living culture in modern dwellings. With the continuous study of Ula culture by many scholars, modern residential design needs to work harder to make the design of Ula's distinctive style systematic, mature and extensive.

\section{CONCLUSION}

In summary, this article first outlines the origin and development of Ula culture, and focuses on the influence of Ula culture on Ula dwellings. Although Ula culture was once forgotten by people, fortunately, many experts, scholars and people in recent years have gradually established awareness of protecting intangible cultural heritage, and Ula culture has been better protected. The influence of Ula culture on residential houses is mainly divided into outdoor environment and indoor layout. The unique lifestyle of Ula people also limits the layout of the interior. Therefore, this paper expounds the unique folk characteristics of Ula culture in interior design, and explores how to practically apply the distinctive Ula culture in interior design, and better inherit it.

\section{REFERENCES}

[1] Agui. Study on the source of Manchurian. Beijing: China International Braodcasting Press, 2016: 17-19.

[2] Tang Jingtai. White mountain and black water: Research on Manchu Communication. Shanghai: Fudan University Press, 2014: 23-26.

[3] Deng Wei. History of Manchu Literature. Shenyang: Liaoning University Press, 2012: 21-23.

[4] Zhang Lihong. The Myths and Legends of Shaman Goddess of the Manchus. Beijing: China Social Sciences Publishing House, 2016: 58-63.

[5] Zhang Jiasheng. Manchu and Changbai Mountain. Shenyang: Liaoning Nationalities Publishing House, 2011: 43-44.

[6] Han Xiaoshi. Manchu residents' custom. Shenyang: Shenyang Press, 2004: 23-25.

[7] Wang Shaozhou, Zhang Jiatai. Chinese National Architecture. Nanjing: Jiangsu Science and Technology Press, 1999: 55-57.

[8] Cao Baoming. Jilin Manchu Paper-cut. Beijing: Nationalities Publishing House, 2010: 45-47.

[9] Shan Linlin. The interior decoration of Zhao's Manchu old house in Yilan County, Heilongjiang Province. Interior Architecture of China, 2008: 9-10.

[10] Lv Ping. Development of Manchu Cultural Tourism Resources in Jilin Province. Social Scientist, 2012: 12-14. 